\title{
Efficacy Aloe Vera in Treatment: A Literature Review
}

\author{
Moh Rozani ${ }^{1 *}$ and Kusbaryanto ${ }^{2}$ \\ ${ }^{1}$ Master of Nursing Student, Muhammadiyah University of Yogyakarta, Indonesia \\ ${ }^{2}$ Lecturer at the Faculty of Medical Sciences, Muhammadiyah University of Yogyakarta, Indonesia
}

*Corresponding author: Moh Rozani, Master of Nursing Student, Muhammadiyah University of Yogyakarta, Indonesia.

Received Date: July 01, 2019

Published Date: July 29, 2019

\begin{abstract}
Introduction: Aloe vera is a medical which has many benefits that is used in medicine to several problems in the health of human body.

Aim: Conducting a literature review study related to efficacy of aloe vera which is used for treatment in healing with body health problems.

Methods: Article searching start on date $10-25$ August 2018 via the CINAHL database, ResearchGate, Pubmed, and ScienceDirect which is used keyword effect AND aloe vera then, selection based on inclusion criteria in the article and after getting results inclusion criteria is done critical appraisal so that relevant articles number of 9 articles.

Results: Of the 9 articles, there were 8 researching articles indicate that using aloe vera has benefits in accelerating the process of wound healing and decrease pain intensity heal burns. There is one researching article indicate date aloe vera can also be used as therapy or treatment in melasma patients with fix function skin pigment. Conclusion: Utilization of treatment using aloe vera proven to accelerate the process of wound healing and decrease some health problems of pain intensity.
\end{abstract}

Keywords: Leaf aloe vera; Efficacy; Treatment

\section{Introduction}

Medical plants are the best source for getting treatment from various disease [1]. Using of natural substances with therapeutic properties has been used since ancient times (Das et al., 2011). At present, several prescribed drugs come from plants [2]. Aloe vera has been used for medical purpose in several cultures for a thousand of years Egypt, India, Mexico, Japan and China [3]. This plant has triangular leaves. Fleshy with jagged edges, yellow tubular flowers and fruits which contain a lot of seeds. Every leaf consults of 3 clear get which of containing 99\% water and the other are made of glucomannan, amino acid, lipids, sterols, vitamins, and middle layers of latex which of bitter yellow sap and contains anthraquinone, glycosides, and thick out layer of is $15-20$ cells referred to as peel that has a protective function, synthesize carbo hydrates and proteins. Inside the skin is a collection of blood vessels responsible to transport substances such as water (xylem) and starch (phloem) [3]. Various aloe vera extracts are mate to be easy is used in medicine to humans like gel, oil, juice, and tablets. In several researches in-vitro indicate that aloe vera leaves showed contain more than 75 nutrients and 200 active compounds, including 20 minerals, 18 amino acids and 12 vitamins. Also contain the most important components which is needed by the human body Mulu $\mathrm{T}$ et al. [4] Aloe vera has vitamins A, B1, B2, B6, B12, C and E. Aloe vera has a high enzyme content (for about 92 enzyme), which makes it a rare source and valuable because of enzyme help the body absorb basic nutrients at the same time purifying it and used as an antifungal, anti-inflammatory, anti-septic, can be used to accelerate the healing process of wounds [5-7]. By looking at kinds of treatment using aloe vera above, so that was done a deep literature to treatment using aloe vera in dealing with health problems.

\section{Aim}

Study researching literature that using aloe vera in treatment or therapy to overcome several health body problems.

\section{Methods}

Searching article begins of that 10-25 august 2018 by using a search strategy via the CINAHL database, Research gate, Pubmed, and ScienceDirect which is used keyword AND aloe vera and 
efficacy AND aloe vera and getting number of articles 4822 in all searching database. Then was checked based on the suitability of the title and abstract reading related to treatment using aloe vera and got as many as 1502 articles. Then continued the selection of articles based on inclusion criteria totaling 305 articles which can be seen in the table one. After the article was collected than a critical appraisal in using format Joanna Briggs Institute (JBI) so that of 305 critical appraisal articles the result of all relevant articles was obtained 12 articles.

\section{Criteria}

Table 1: List of article criteria for doing literature review.

\begin{tabular}{|c|c|}
\hline Inclusion & Exclusion \\
\hline $\begin{array}{c}\text { Researching must be related to } \\
\text { treatment of health problems that } \\
\text { use aloe vera }\end{array}$ & $\begin{array}{c}\text { Publication only as a letter to } \\
\text { editor, abstract only and editorial }\end{array}$ \\
\hline $\begin{array}{c}\text { The researching explains the effect } \\
\text { of aloe vera }\end{array}$ & Researching was done to animal \\
\hline $\begin{array}{c}\text { Complete text of researching and in } \\
\text { english }\end{array}$ & \\
\hline
\end{tabular}

Table 2: Studies included in the literature review.

\begin{tabular}{|c|c|c|c|c|c|}
\hline No. & Author (Yessar) & Purpose & Study Design & Sample & Relevant Findings \\
\hline 1 & $\begin{array}{c}\text { Ghafarzadeh \& } \\
\text { Eatemadi } \\
\text { (2017) }\end{array}$ & $\begin{array}{c}\text { Determine the efficacy of } \\
\text { aloe vera liposome (AGE) } \\
\text { in melasma of pregnant } \\
\text { women }\end{array}$ & $\begin{array}{l}\text { Double-blinded, } \\
\text { randomized } \\
\text { clinical trial }\end{array}$ & $\begin{array}{l}\text { Randomization } \\
\text { Treatment group } \\
\text { (topical liposome } \\
\text { encapsulated aloe vera } \\
\text { gel) as many as } 90 \\
\text { patients } \\
\text { Control group (extract } \\
\text { aloe vera gel) as many } \\
\text { as } 90 \text { patients }\end{array}$ & $\begin{array}{l}\text { Melasma treatment in pregnant women, } \\
\text { there is an increase to score melasma } \\
\text { area severity indeks (MASI) } 32 \% \text { in the } \\
\text { liposome treatment group compared } \\
\text { aloe vera extract with increase } 10 \% \text { in } \\
\text { the AGE group only }\end{array}$ \\
\hline 2 & $\begin{array}{l}\text { S.Pol et al } \\
(2016)\end{array}$ & $\begin{array}{l}\text { Effect of aloe vera juice and } \\
\text { gel into oral lichen planus } \\
\text { symptomatic management }\end{array}$ & $\begin{array}{l}\text { A randomized } \\
\text { clinical study } \\
\text { design }\end{array}$ & $\begin{array}{l}\text { Randomization } \\
\text { A group (juice and gel) } \\
\text { as many as } 15 \text { patients } \\
\text { B group (gel) as many } \\
\text { as } 15 \text { patients }\end{array}$ & $\begin{array}{l}\text { Visual analog scale (Vas) average score } \\
\text { both groups indicate statistically signif- } \\
\text { icant decrease ( } \mathrm{P}<0,001 \text { ). But there is } \\
\text { difference into decrease in the VAS score } \\
\text { as followers: } \\
\text { A group the average Vas score is reduced } \\
\text { from } 8,93 \text { become } 8,00 \text { (one week), 6,43 } \\
\text { (two weeks), 3,29 (four weeks) and 0,29 } \\
\text { (eight weeks). } \\
\text { B group the average Vas score in B group } \\
\text { is reduced from 6,93 become 6,64 (one } \\
\text { week), 5,43 (two weeks), 3,93 (four } \\
\text { weeks), and 2,14 (eight weeks). }\end{array}$ \\
\hline 3 & $\begin{array}{l}\text { Mansouri et al } \\
\qquad(2016)\end{array}$ & $\begin{array}{l}\text { Effect of aloe vera solution } \\
\text { to stomatitis and pain } \\
\text { intensity to patient who } \\
\text { undergo chemotherapy } \\
\text { procedure }\end{array}$ & $\begin{array}{l}\text { A randomized } \\
\text { controlled clinical } \\
\text { trial }\end{array}$ & $\begin{array}{l}\text { Randomization treat- } \\
\text { ment group (aloe vera } \\
\text { solution) as many as } 32 \\
\text { patients. Control group } \\
\text { as many as } 32 \text { patients }\end{array}$ & $\begin{array}{l}\text { Aloe vera solution as a mouthwash } \\
\text { significantly reduces the intensity of } \\
\text { stomatitis and pain in the conversion } \\
\text { group was compared to the control } \\
\text { group. Significant differences were } \\
\text { observed between } 2 \text { group in the day } \\
\text { 3-14 with statistical test results P: } 0,001 \\
\text { (stomatitis intensity) use the } \\
\text { checklist of stomatitis intensity from } \\
\text { World Association Health (WHO) with } \\
\text { value P: } 0,001 \text { (pain } \\
\text { intensity) using visual analog scale (Vas) }\end{array}$ \\
\hline 4 & $\begin{array}{l}\text { Panahi et al } \\
\text { (2015) }\end{array}$ & $\begin{array}{c}\text { Evaluate the effect of aloe } \\
\text { vera oil cream (AVO cream) } \\
\text { in process of healing chronic } \\
\text { wounds }\end{array}$ & $\begin{array}{c}\text { Randomized } \\
\text { double-blind } \\
\text { comparator } \\
\text { controlled parallel } \\
\text { group trial }\end{array}$ & $\begin{array}{c}\text { Randomization } \\
\text { Treatment group (AVO } \\
\text { cream) as many as } 30 \\
\text { patients } \\
\text { Control group } \\
\text { (Phenytoin cream) as } \\
\text { many as } 30 \text { patients }\end{array}$ & $\begin{array}{l}\text { Wound: size, depth, and edge. } \\
\text { Necrosis: type and number of tissues } \\
\text { Exudate: type and amount. } \\
\text { Total wound healing score indicate } \\
\text { improvement with AVO cream }(\mathrm{P}<0,001) \\
\text { and phenytoin }(0,01) \text {. Although both } \\
\text { treatments reduce Vas score, AVO } \\
\text { efficacy increased significantly. }\end{array}$ \\
\hline 5 & $\begin{array}{l}\text { Rahmani et al } \\
\qquad \text { (2014) }\end{array}$ & $\begin{array}{l}\text { Evaluate the effect of aloe } \\
\text { vera cream } 0,5 \% \text { in the } \\
\text { treatment of chronic anal } \\
\text { fissure }\end{array}$ & $\begin{array}{l}\text { A prospective } \\
\text { double-blind } \\
\text { clinical trial }\end{array}$ & $\begin{array}{c}\text { Randomization } \\
\text { Treatment group (aloe } \\
\text { vera cream } 0,5 \% \text { ) as } \\
\text { many as } 30 \text { patients } \\
\text { Control group as many } \\
\text { as } 30 \text { patients }\end{array}$ & $\begin{array}{c}\text { There was statistically significant } \\
\text { difference in chronic rectal fissure pain, } \\
\text { bleeding on damage and wound healing } \\
\text { before and at the end of first week } \\
\text { treatment also compared with control } \\
\text { group }\end{array}$ \\
\hline
\end{tabular}




\begin{tabular}{|c|c|c|c|c|c|}
\hline 6 & $\begin{array}{l}\text { Shahzad \& } \\
\text { Ahmed } \\
\text { (2013) }\end{array}$ & $\begin{array}{l}\text { The efficacy aloe vera gel } \\
\text { was compared with } 1 \% \\
\text { sulfadiazine silver cream as } \\
\text { a dressing for the treatment } \\
\text { superficial and partial burns }\end{array}$ & Compative study & $\begin{array}{l}\text { Randomization } \\
\text { Treatment group (aloe } \\
\text { vera gel) as many as } 30 \\
\text { patient's comparison } \\
\text { group (1\% silver } \\
\text { sulfadiazine cream) as } \\
\text { many as } 20 \text { patients }\end{array}$ & $\begin{array}{l}\text { Patients was treated with aloe vera gel, } \\
\text { healing of burns was very fast compared } \\
\text { to patients treated silver sulfadiazine } 1 \% \\
\text { related to duration of wound } \\
\text { epithelialization, decreased paint } \\
\text { intensity }\end{array}$ \\
\hline 7 & $\begin{array}{l}\text { Jornet et al } \\
\text { (2012) }\end{array}$ & $\begin{array}{l}\text { Evaluate the efficacy of aloe } \\
\text { vera gel which is applied in } \\
\text { combination with tongue } \\
\text { protector to patients } \\
\text { burning mouth syndrome }\end{array}$ & $\begin{array}{l}\text { Prospective } \\
\text { randomized dou- } \\
\text { ble-blind clinical } \\
\text { evaluation }\end{array}$ & $\begin{array}{l}\text { Randomization } \\
\text { Group } 1 \text { (tongue } \\
\text { protector) as many as } \\
25 \text { patients. Group } 2 \\
\text { (tongue protector and } \\
\text { aloe vera) as many as } \\
24 \text { patients } \\
\text { Group } 3 \text { (tongue } \\
\text { protector and placebo) } \\
\text { as many as } 22 \text { patients }\end{array}$ & $\begin{array}{l}\text { Analog visual scale pain value improved } \\
\text { for all three researching groups but } \\
\text { without statistically significant } \\
\text { differences among groups P: } 0,210 \text {. But } \\
\text { overall clinical repairing is bigger for } \\
\text { group 2, with differences almost } \\
\text { reaching significance }\end{array}$ \\
\hline 8 & $\begin{array}{l}\text { Babaee et al } \\
\quad(2012)\end{array}$ & $\begin{array}{l}\text { Evaluation giving aloe vera } \\
\text { gel to healing alpthous } \\
\text { minor oral cavity }\end{array}$ & $\begin{array}{l}\text { Double-blind } \\
\text { (case control) } \\
\text { clinical trial }\end{array}$ & $\begin{array}{c}\text { Randomization } \\
\text { Treatment group (aloe } \\
\text { vera gel) as many as } 22 \\
\text { patients } \\
\text { Control group (placebo) } \\
\text { as many as } 22 \text { patients }\end{array}$ & $\begin{array}{l}\text { Aloe vera gel oral } 2 \% \text { effective to reduce } \\
\text { pain score, size of wound also to speed } \\
\text { accelerate wound healing stomatitis } \\
\text { alpthous compared control group }\end{array}$ \\
\hline 9 & $\begin{array}{l}\text { Eshghi et al } \\
\qquad(2010)\end{array}$ & $\begin{array}{c}\text { Evaluate the effect aloe } \\
\text { vera cream in reducing pain } \\
\text { and accelerating process of } \\
\text { post-surgery wound healing, } \\
\text { post defection } \\
\text { (hemorrhoidectomy) }\end{array}$ & $\begin{array}{l}\text { A prospective, } \\
\text { randomized dou- } \\
\text { ble-blind placebo } \\
\text { control trial }\end{array}$ & $\begin{array}{c}\text { Randomization } \\
\text { Treatment group (aloe } \\
\text { vera cream) as many as } \\
24 \text { patients } \\
\text { Control group (placebo) } \\
\text { as many as 25 patients }\end{array}$ & $\begin{array}{l}\text { Patients in the topical aloe vera cream } \\
\text { group significantly decreased } \\
\text { post-operative pain at } 12,24 \text {, and } 48 \\
\text { hours post-surgery P: }<0,001 \text {. Patients } \\
\text { who received aloe vera cream } \\
\text { experienced a significantly helps wound } \\
\text { healing in postsurgery patients for } 2 \\
\text { weeks } P:<0,001\end{array}$ \\
\hline
\end{tabular}

\section{Results}

Learnt 9 articles found that aloe vera functional to speed up the healing process of wounds into reduce the intensity of pain in the treatment of oral lichen planus, stomatitis, diabetes mellitus, pressure ulcers, venous ulcers, chronic anal fissure, heal burns, burning mouth sydrome, alpthous minor, operation post [8]. So that could be said that the content of aloe vera has function to speed up the healing process of wounds and could reduce the intensity of pain which is due to several health body problems. There is one articles that has different to the efficacy of aloe vera, other to speed up the healing process of wounds and reduce the intensity of pain which one aloe vera gel was encapsulated in liposome was used in the healing melasma process. Because the content aloe vera gel has function as a skin pigmentation modifying agent [9]. Literature learn identified from 9 papers that have been done with critical steps so that from 9 articles discussing aloe vera which are managed or extracted in various forms and has different properties. Application in several treatment related to health problems in the forms of gel cream, juice, and solution of follows.

\section{Aloe vera gel}

Four researching articles identified the efficacy of aloe vera gel nonetheless there are differences in other of research. Ghafarzadeh M \& Eatemadi A [9] using aloe vera gel extract (AGE) 0,5\% and encapsulated liposomes $1 \%$ weight of treatment given to melasma patient with significant results. Shahzad MN \& Ahmed N [10] researching using aloe vera (Aloe Tone Je IR) get which is not purified and has 98\% gels used for the treatment of superficial burns and partial with the result that aloe vera get can speed up the healing process of wounds and reduce the intensity of pain. López jornet $\mathrm{P}$ et al. [11] identify aloe vera barbadensis gel combined and tongue protector it was found that using of aloe vera gel and tongue protector can reduce duration of wound healing to burning mouth syndrome patients. Others researching's that reduce pain score and wound size but also accelerates the healing of alpthous stomatitis wound [12].

\section{Aloe vera cream}

Three researching articles identified aloe vera which is managed into the form of cream. Researching by Babaee $\mathrm{N}$ et al. [12] was found using cream of aloe vera oil (AVO cream) toward wounds recovery with results with significant improvement results using pain assessment tools (VAS), AVO cream efficacy statistical test scores increased significantly $(\mathrm{p}<0.001)$. Rahmani $\mathrm{N}$ et al. [13] identified the effect of aloe vera cream $0,5 \%$ in chronic anal fissure treatment and it was found that using aloe vera cream could reduce pain and accelerate the process of wound healing during chronic anal fissure treatment. Eshghi F et al. [14] also identified the using of aloe vera cream into reduce pain and accelerate the process of post-surgery wound healing, post defection (hemorrhoidectomy) and found that aloe vera cream significantly reduced post-surgery pain at 12, 24, 48 hours and 2 weeks post-surgery and patients who is receiving aloe vera cream has decreased when take number two significantly at 24 and 48 hours after hemorrhoidectomy and 
aloe vera cream significantly helps wound healing to post-surgery patient during 2 weeks.

\section{Aloe vera juice and gel}

One researching has been done by Pol JS et al. [8] identified combination of aloe vera juice and gel in oral symptomatic lichen planus treatment, the said by combining treatment juice and gel in symptomatic oral lichen planus treatment reduce the duration of pain.

\section{Aloe vera solution}

Mansouri P et al. [15] using aloe vera solution to stomatitis and pain intensity in patient who undergoing chemotherapy procedures and the results were obtained that using of aloe vera solution to reduce the pain of chemotherapy to stomatitis patients are very effective with statistical test results on third day (on the 3rd day) - 14th day P : 0.001 (stomatitis intensity) and P: 0.001 (pain intensity).

\section{Discussion}

Pain is common symptoms of many medical problems. Which indicates tissue damage [16]. Pain has several types such as acute pain, chronic pain, migraine, musculoskeletal, postsurgery pain, neuropathic pain, nociceptic and others [17]. One of causes of pain is wound caused by various health problems. Most researching literature reviews that discuss the using of aloe vera therapy through skin. Skin is one of organs as a protector which has function as a receiver regulate humidity, temperature modulation [18]. In 9 researching articles conducted by literature review identify ways to speed the wound healing process and reduce intensity of paint from various health problems with treatment using aloe vera. But we can the type or form of aloe vera which given in the treatment is gel, cream, solution, juice and oil which given through skin. Of 9 articles there was only one researching article which investigate treatment with using aloe vera in a type of solution in stomatitis done by gargling. Whereas it is known that one of the most effective absorption of drugs through skin is solution that aloe vera is very useful for used to wound healing process. Aloe vera gel topical using is done by application it to skin as medicine for skin conditions such as burns, psoriasis, wound and can be taken orally (through mouth) for conditions including osteoarthritis, intestinal disease, fever [19]. Pharmacological action of this get has assessed through in vitro and in vivo experiments. Preclinical researching results provide evidence that aloe vera has activity as anti-inflammatory, anti-rheumatic, anti-bacterial, and hypoglycemic [20]. Health benefits aloe vera include the application in wound healing process, treat burns and given to protection against skin damage from Aloe vera is a plan that can produce X-rays [21]. Aloe vera is a plant that can produce sap and gel. The gel is extracted from the leaves, and this is the most widely used substance as a treatment [22]. Different from traditional treatment modalities, aloe vera will great reduce medical cost intended as complementary therapy [23-25].

This paper is still limited in research using aloe vera to speed up the wound healing process and reduce intensity of pain from various health problems, in the type of gel, juice, cream, and especially solution and liquid. More researching is needed on the efficacy of aloe vera in curing various health problems.

\section{Conclusion}

The using of treatment that uses aloe vera has been proven to accelerate the wound healing process and reduce pain intensity in some health problems than other comparison groups and also serves as an improvement in the skin pigmentation.

\section{Acknowledgements}

We would like to thank to the lectures nursing Universitas Muhammadiyah Yogyakarta who have given support in solving this literature review.

\section{Conflict of Interest}

None.

\section{References}

1. Sahu PK, Giri DD, Singh R, Pandey P, Gupta S, et al. (2013) Therapeutic and Medicinal Uses of Aloe vera: A Review. Pharmacology Pharmacy 4: 599-610.

2. Nimma VL, Talla HV, Bairi JK, Gopaldas M, Bathula H, et al. (2017) Holistic healing through herbs: Effectiveness of aloe vera on post extraction socket healing. J Clin Diagn Res 11(3): ZC83-ZC86.

3. Surjushe A, Vasani R, Saple D (2008) Aloe vera: A short review. Indian J Dermatol 53(4): 163-166.

4. Mulu T, Teshale F, Gemeda S, Sahu O (2015) Medicated Evaluation of Aloe Vera: Overview on Characteristics and Application. World Journal of Nutrition and Health 3(1): 1-7.

5. Park MY, Kwon HJ, Sung MK (2011) Dietary aloin, aloesin, or aloe-gel exerts anti-inflammatory activity in a rat colitis model. Life Sci 88(1112): 486-492.

6. Rathor N, Mehta AK, Sharma AK, Mediratta PK, Sharma KK (2012) Acute effect of Aloe vera gel extract on experimental models of pain. Inflammation 35(6): 1900-1903.

7. Panahi Y, Izadi M, Sayyadi N, Rezaee R, Member F, et al. (2015) Comparative trial of Aloe vera/ olive oil combination cream versus phenytoin cream in the treatment of chronic wounds. J Wound Care 24(10): 459-465.

8. Pol JS, Patil BA, Sodhi A, Tadiparthi J (2016) Evaluation of Therapeutic Effect of Aloe Vera Juice and Gel in the Management of Symptomatic Oral Lichen Planus. International Journal of Medical and Dental Sciences 5(2): 1138.

9. Ghafarzadeh M, Eatemadi A (2017) Clinical efficacy of liposomeencapsulated Aloe vera on melasma treatment during pregnancy. J Cosmet Laser Ther 19(3): 181-187.

10. Shahzad MN, Ahmed N (2013) Effectiveness of Aloe Vera Gel compared with $1 \%$ silver sulphadiazine cream as burn wound dressing in second degree burns. J Pak Med Assoc 63(2): 225-230.

11. López jornet P, Camacho Alonso F, Molino Pagan D (2012) Prospective, randomized, double-blind, clinical evaluation of Aloe vera Barbadensis, applied in combination with a tongue protector to treat burning mouth syndrome. J Oral Pathol Med 42(4): 1-7.

12. Babaee N, Zabihi E, Mohseni S, Moghadamnia AA (2012) Evaluation of the therapeutic effects of Aloe vera gel on minor recurrent aphthous stomatitis. Dent Res J 9(4): 381-385.

13. Rahmani N, Khademloo M, Vosoughi K, Assadpour S (2014) Effects of Aloe vera cream on chronic anal fissure pain, wound healing and hemorrhaging upon defection: A prospective double-blind clinical trial. Eur Rev Med Pharmacol Sci 18(7): 1078-1084. 
14. Eshghi F, Hosseinimehr SJ, Rahmani N, Khademloo M, Norozi MS, et al. (2010) Effects of Aloe vera cream on posthemor rhoidectomy pain and wound healing: results of a randomized, blind, placebo-control study. J Altern Complement Med 16(6): 647-650.

15. Mansouri P, Haghighi M, Beheshtipour N, Ramzi M (2016) The Effect of Aloe Vera Solution on Chemotherapy-Induced Stomatitis in Clients with Lymphoma and Leukemia: A Randomized Controlled Clinical Trial. Int J Community Based Nurs Midwifery 4(2): 119-126.

16. Hylands White N, Duarte RV, Raphael JH (2017) An overview of treatment approaches for chronic pain management. Rheumatol Int 37(1): 29-42.

17. Nalamachu S (2017) An Overview of Pain Management: The Clinical Efficacy and Value of Treatment. Am J Manag Care 19: s261-s266.

18. Childs DR, Murthy AS (2017) Overview of Wound Healing and Management. Surg Clin North Am 97(1): 189-207.

19. Hale T, Rowe H (2017) Aloe vera. In Medications and mothers' milk online, pp. 1-4.
20. Miroddi M, Navarra M, Calapai F, Mancari F, Giofrè SV, et al. (2015) Review of clinical pharmacology of Aloe vera L. in the treatment of psoriasis. Phytother Res 29(5): 648-655.

21. Ahlawat KS, Khatkar BS (2011) Processing, food applications and safety of aloe vera products: A review. J Food Sci Technol 48(5): 525-533.

22. Bashir A, Saeed B, Mujahid TY, Jehan N (2011) Comparative study of antimicrobial activities of Aloe vera extracts and antibiotics against isolates from skin infections. African Journal of Biotechnology 10(19): 3835-3840.

23. Manigandan T, Elumalai M, Cholan P, Kaur R, Mangaiyarkarasi S (2015) Benefits of Aloe vera in dentistry. J Pharm Bioallied Sci 7(5): 255-259.

24. Das S, Mishra B, Gill K, Ashraf MS, Singh AK, et al. (2011) Isolation and characterization of novel protein with anti-fungal and anti-inflammatory properties from Aloe vera leaf gel. Int J Biol Macromol 48(1): 38-43.

25. Leite Silva V, Almeida M De, Fradin A, Grice JE, Roberts MS (2012) Delivery of drugs applied topically to the skin. Expert Review of Dermatology 7(4): 383-397. 